\title{
The importance of flower cells for the early diagnosis of acute adult T-cell leukemia/lymphoma with skin involvement
}

\author{
JUSSAMARA BRITO SANTOS ${ }^{1}$, LOURDES FARRÉ ${ }^{2}$, EVERTON DA SILVA BATISTA ${ }^{2}$, \\ HERBERT HENRIQUE SANTOS ${ }^{3}$, MARIA DAS GRAÇAS SILVA VIEIRA ${ }^{4}$ \& \\ ACHILÉA L. BITTENCOURT ${ }^{4}$ \\ ${ }^{1}$ Escola Bahiana de Medicina e Saúde Pública, Fundação Baiana para o Desenvolvimento da Ciência, Salvador, Bahia, \\ Brasil, ${ }^{2}$ Laboratório de Patologia Experimental (LAPEX), CPqGM-FIOCRUZ, Salvador, Bahia, Brasil, ${ }^{3}$ Laboratório de \\ Imunologia, Instituto de Ciências da Saúde, Universidade Federal da Bahia, Brasil and ${ }^{4}$ Departmento de Patologia, \\ Complexo Hospitalar Universitário Prof. Edgard Santos (Com-HUPES) Universidade Federal da Bahia, Brasil
}

\section{To the Editor,}

Adult T-cell leukemia/lymphoma (ATL) is an aggressive, mature T-cell malignancy caused by the human T-cell lymphotropic virus type I (HTLV-1). ATL is clinically classified into the following types: acute, chronic, lymphomatous, smoldering or primary cutaneous tumoral $[1,2]$. The disease manifests itself in the skin as erythroderma, plaques, papules and, less frequently, as nodules and tumors [3], the frequency of skin involvement varying from 43 to $72 \%$ [2]. We describe a case of acute ATL with skin involvement in which early diagnosis was made based on the finding of flower cells in peripheral blood.

A 33-year-old male of African descent, presented one month history of cutaneous lesions. He also complained of weight loss and weakness of a few days' duration. A serologic study revealed the patient to be HTLV-1-positive and HIV-negative. He had been breastfed as an infant but had no history of blood transfusion. Physical examination revealed multiple papules and nodules on his face (Figure 1A), on the ears, and on the anterior portion of his chest (Figure 1B) associated with mild cervical and inguinal lymphadenopathy. A great number of flower cells were observed in a peripheral blood smear (Figure 2). The patient had a lymphocyte count of 62000 cells/ $\mathrm{mm}^{3}$, serum lactate dehydrogenase $(\mathrm{LDH})$ levels of $4000 \mathrm{U} / 1$ and normal calcium levels. A peripheral blood sample was analyzed by flow cytometry and the cell surface markers indicated: CD2 94\%;
CD3 99\%; CD4 99\%; CD5 92\%; CD25 82\%; and TCR $\alpha \beta 92 \%$. No expression was observed with the markers CD7, CD8 and TCR $\gamma \delta$. A bone marrow smear revealed lymphomatous infiltration. Two days following hospitalization, hypercalcemia was detected $(12.2 \mathrm{mg} / \mathrm{dl})$. Cervical, chest and abdominal tomographies showed generalized lymphadenomegaly, and hepatosplenomegaly. Skin biopsy revealed epidermotropism of lymphocytes and Pautrier's microabscesses with atypical lymphocytes. A dense and diffuse infiltration of large, atypical lymphocytes was observed in the dermis. The lymphocytes were $\mathrm{CD} 2+, \mathrm{CD} 3+$, $\mathrm{CD} 4+, \mathrm{CD} 5+, \mathrm{CD} 7-, \mathrm{CD} 8-, \mathrm{CD} 20-, \mathrm{CD} 25+$, $\mathrm{CD} 30-, \mathrm{CD} 79 \mathrm{a}-$, and OPD4+. The Ki-67 proliferative index was $70 \%$. HTLV-1 monoclonal integration was detected in peripheral blood mononuclear cells by inverse long polymerase chain reaction [4]. The patient used interferon- $\alpha$ (IFN- $\alpha$ ) and zidovudine (ZDV) for two days but refused this treatment because of side effects. The therapeutic regimen was then changed to chemotherapy using CHOP (Cyclophosphamide, Hydroxydaunorubicin, Oncovin, Prednisone). The condition of the patient deteriorated and he died of septic shock six weeks after diagnosis.

At first, diagnosis was based on the discovery of numerous flower cells in peripheral blood because these cells are considered to be pathognomonic of ATL [5]. They are generally present in the acute form but may also be seen occasionally in smoldering and chronic cases [1]. In addition to the large number of

Correspondence: Achiléa L. Bittencourt, Serviço de Anatomia Patológica, Complexo Hospitalar Universitário Prof. Edgard Santos, Rua Dr. Augusto Viana s/nº, Canela - CEP: 40.110-060, Salvador, Bahia, Brazil. Tel/Fax: +55 713283 8016. E-mail: achilea@uol.com.br 

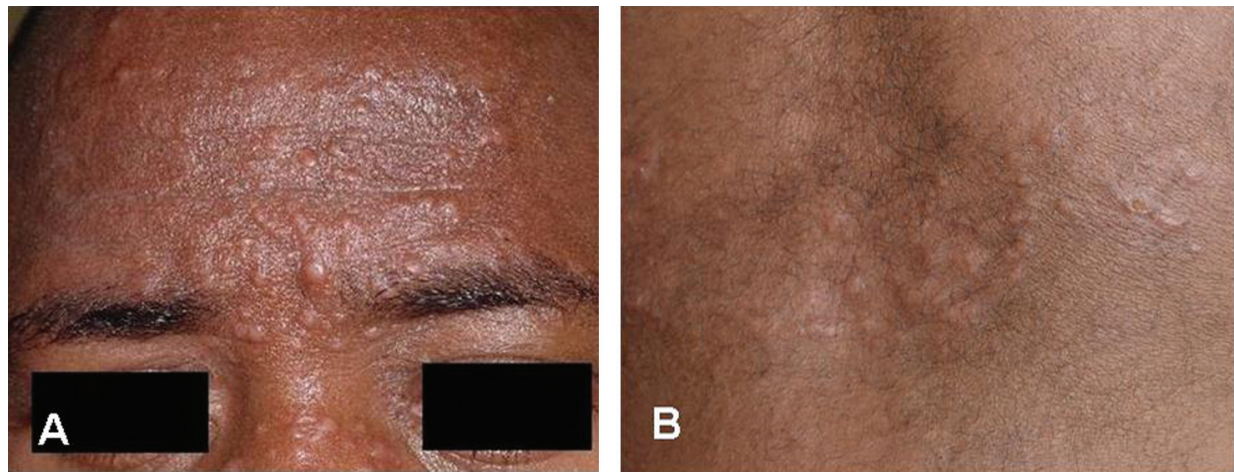

Figure 1. Papulo-nodular lesions: A. On the face; B. On the anterior aspect of the thorax.

flower cells, high lymphocytosis and high levels of $\mathrm{LDH}$ were also present as well as involvement of the lymph nodes and bone marrow enabling the diagnosis of acute ATL. The absence of hypercalcemia in the first days of hospitalization constituted an atypical pattern for acute ATL; however, hypercalcemia developed within a few days of hospitalization. The flow cytometry and the immunohistochemistry in the present case showed immunophenotypes suggestive of ATL, such as CD7-, CD8- and CD25+ [6].

Diagnosis of ATL also requires confirmation of the presence of serum antibodies against HTLV-1 and, whenever possible, the presence of integrated proviral sequences in order to make the differential

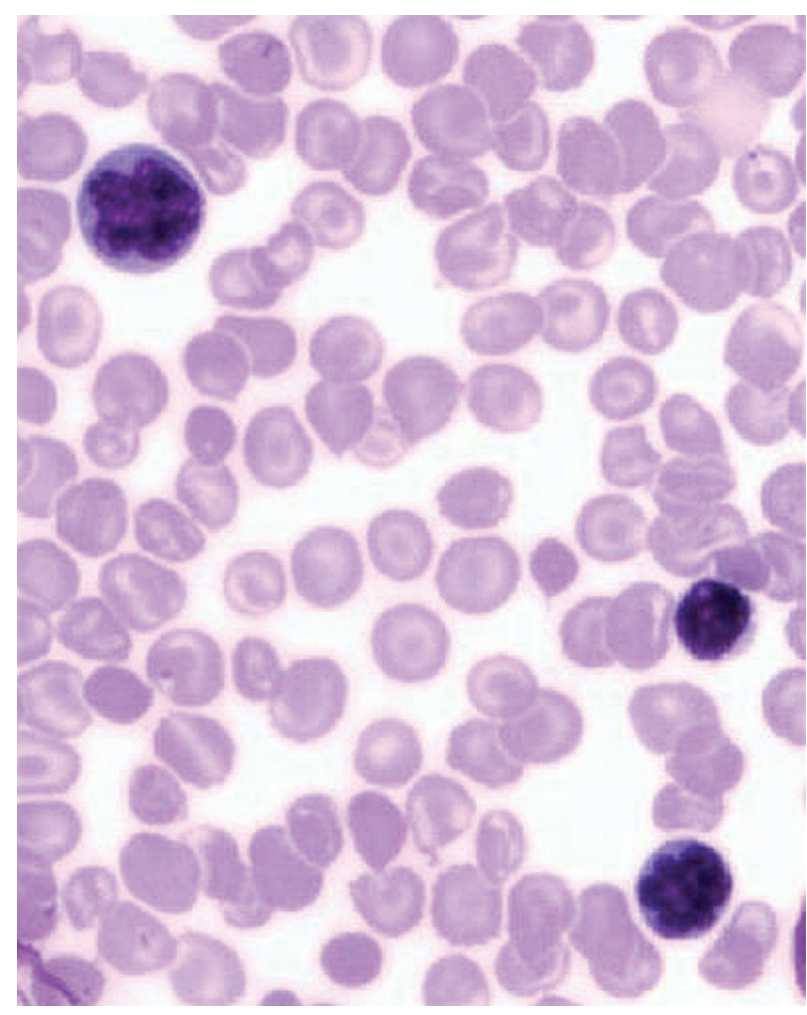

Figure 2. Presence of two lymphocytes with condensed chromatin and markedly polylobulated nucleus (flower cells). Wright, X 1000. diagnosis between ATL and other types of leukemia/ lymphoma occurring in HTLV-1 carriers. It is wellknown that it is histologically impossible to differentiate ATL from other T-cell lymphomas unrelated to this virus occurring in HTLV-1 carriers. This differentiation is important, because the prognosis and treatment of ATL are different from those of other types of leukemia/lymphoma [2]. The confirmation of HTLV-1 proviral integration in the present case also demonstrates the relationship between the virus and the leukemia/lymphoma.

The acute form of ATL is one of the most severe types and one that requires prompt diagnosis to ensure that appropriate therapy is initiated as early as possible. The median survival time of patients with acute ATL varies from four to six months $[1,2]$. However, in the present case, the patient survived only six weeks after diagnosis because ATL responds poorly to chemotherapy. Nowadays the treatment of choice is IFN- $\alpha / Z D V$, a therapeutic regimen that has led to a considerable improvement in the prognosis of the patients [7].

As techniques for the detection of proviral integration are only available in a few research centers, the discovery of flower cells in peripheral blood smears is very important since this finding constitutes a simple technique that permits immediate diagnosis of acute ATL.

Considering that the skin is frequently involved in the different types of ATL, skin lesions may represent the first sign of the disease. It is important that ATL be considered in the differential diagnosis of cutaneous papulo-nodular lesions. Dermatologists need to be aware of these manifestations and be informed with respect to diagnosis.

\section{Acknowledgments}

The authors are grateful to Dr Augusto Mota and to Dr Lorena Marçal for their contribution to this study. This study was supported by Conselho Nacional de Pesquisa (CNPq) and Fundação de Apoio a Pesquisa 
do Estado da Bahia (FAPESB). The authors have no conflicts of interest.

Declaration of interest: The authors report no conflicts of interest. The authors alone are responsible for the content and writing of the paper.

\section{References}

[1] Shimoyama M. Diagnostic criteria and classification of clinical subtypes of adult T-cell leukaemia-lymphoma. Br J Hematol 1991;79:428-37.

[2] Bittencourt AL, Vieira MG, Brites CR, Farré L, Barbosa HS. Adult T-cell leukemia/lymphoma (ATL) in Bahia, Brazil: Analysis of prognostic factors in a group of 70 patients. Am J Clin Pathol 2007;128:875-82.

[3] Bittencourt AL, Barbosa HS, Vieira MG, Farré L. Adult T-cell leukemia/lymphoma (ATL) presenting in the skin:
Clinical, histological and immunohistochemical features of 52 cases. Acta Oncol 2009;48:598-604.

[4] Etoh K, Tamiya S, Yamaguchi K, Okayama A, Tsubouchi H, Ideta $\mathrm{T}$, et al. Persistent clonal proliferation of human T-lymphotropic virus type I-infected cells in vivo. Cancer Res 1997;57:4862-7.

[5] Tsukasaki K, Hermine O, Bazarbachi A, Ratner L, Ramos JC, Harrington W Jr, et al. Definition, prognostic factors, treatment, and response criteria of adult T-cell leukemialymphoma: A proposal from an international consensus meeting. J Clin Oncol 2009;27:453-9.

[6] Ohshima K, Jaffe ES, Kikuchi M. Adult T-cell leukaemia/ lymphoma. In Swerdlow SH, Campo E, Harris NL, Jaffe ES, Pileri SA, Stein H, et al. WHO classification of tumours of haematopoietic and lymphoid tissues. Lyon; WHO: 2008. p 281-4.

[7] Bazarbachi A, Panelatti G, Ramos JC, Tortevoye P, Otrock Z, Taylor G, et al. A worldwide meta-analysis on the use of zidovudine and interferon-alpha for the treatment of adult T-cell leukemia/ lymphoma. Blood 2007;110:610a-1a. 